\title{
THE COMMERCE CLAUSE AND STATE SALES TAXES : RECENT DEVELOPMENTS
}

THE ERA of social consciousness which followed the business depression has witnessed a revolutionary retailoring of the old commerce clause concepts ${ }^{1}$ developed under a philosophy of individual rights. The sweeping changes occurring in each area of commerce clause application have progressed in apparent disregard of contradictory developments in other related fields. Social forces behind state police regulation have prompted an increasingly narrow concept of interstate commerce in order to permit effective expansion of state police power. 2 Simultaneously, similar social forces have caused an unprecedented broadening of the same concept in order to uphold federal regulatory legislation. ${ }^{3}$

In addition to the logical feat of erecting two concurrent but contradictory constructions of the commerce clause for police power purposes, the Court has also been successful in establishing a third and even more isolated category ${ }^{4}$ -the interpretation of the commerce clause in relation to state taxation of industries which move their products across state lines. When property taxation was the backbone of the state fiscal system, the rule that no state could place a burden on interstate commerce was not an imposing restriction. But now that sales and related taxes, ${ }^{5}$ involving transactions that often reach

1. "Congress shall have power to regulate commerce with foreign nations and among the several states." U. S. Coxst. Art. I, $\S \&, \mathrm{cl}$. 3. The silence of Congress on the subject of the power of the states under this clause has generally been interpreted to prohibit the regulation of such commerce by the states, and the exercise of both the taxing and the police power has been held to constitute such regulation. Philadelphia \& So. Steamship Co. v. Pennsylvania, 122 U. S. 326 (1887) ; Postal Tel. Cable Co. v. Adams, 155 U. S. 688, 695-696 (1895). But see Adams AIfg. Co. v. Storen, 304 U. S. 307 (1938) (Black, J., dissenting).

2. See Clyde Mallory Lines v. Alabama ex rel. State Docks Comm., 296 U. S. 261 (1935) ; Townsend v. Yeomans, 301 U. S. 441 (1937). But cf. Baldwin v. Seelig, Inc., 294 U. S. 511 (1935).

3. National Labor Relations Board v. Jones \& Laughlin Steel Corp., 301 U. S. 1 (1937), Comment (1937) 25 CaLIF. L. REv. 593. This case holds that the Federal Government has power to regulate where interstate commerce is "affected" by the operntion regulated. See (1938) 47 YALE L. J. 1221.

4. It has been repeatedly indicated by the Supreme Court that the areas open to federal regulation and those where state taxation is permissible are not mutually exclusive. See Stafford v. Wallace, 258 U. S. 495, 525 (1922); National Labor Relations Board v. Jones \& Laughlin Steel Corp., 301 U. S. 1, 35 (1937). But see Carter v. Carter Coal Co., 298 U. S. 238, 302 (1936).

5. Such taxes include a retail sales tax, a general sales tax, a gross receints tax, a gross income tax, and the various forms of compensating use taxes. Sec Hurg \& Suour, The Sales Tax in the Axrerican States (1934) 3-4; Departase:it of Legislative Research and Drafting (1932, Duke Univ.) pub. no.1. Where the interstate sale of goods is involved, the cases do not distinguish between excise taxes, license taxes, and gross sales taxes but treat them all as privilege taxes, as opposed to property taxes. Gavit, The Coararerce Clause (1932) § 170. 
across state borders, have become indispensable sources of reventu, ${ }^{0}$ the doctrine stands as a serious barrier to state fiscal policies. As a result, the demand for change in the tax doctrines adhering to the commerce clatuse is approaching a crescendo never before attained. Rumblings in the tax compartment of the commerce concept indicate that readjustment is already occurring. It is the purpose of this Comment to point out some changes which have been effected and others which may take place.

The orthodox rule has long been that any tax which burdens interstate commerce directly is invalid, even though non-discriminatory, ${ }^{7}$ while a tax which constitutes an indirect burden is constitutional only so long as it does not discriminate in favor of intrastate commerce. ${ }^{8}$ Translated into terms of actual cases, these concepts have fathered numerous refined distinctions between interstate and intrastate commerce and between direct and indirect burdens. These distinctions seem founded upon dry legal logic rather than any consideration of the practical effect of the taxes concerned. A privilege tax measured by the gross receipts of a company engaged in interstate commerce has been held to impose a direct burden upon such commerce becaltse the tax "affects each transaction in proportion to its magnitude" and must be

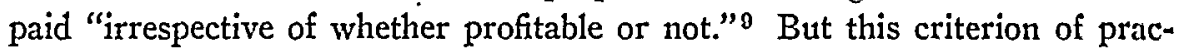
tical effect has yielded to the press of legal dogma in the case of an ad valorcm property tax. Even though it likewise may cause the interstate merchant a net loss, such a tax on property located within the state will be upheld, if non-discriminatory, on the rationale that it constitutes an indirect and not a direct burden on commerce. ${ }^{10}$ Moreover, taxes on gross income of an interstate business have been upheld when viewed as being in lieu of a property tax which would otherwise be imposed by the taxing state ${ }^{11}$ or where there is some fair method provided for apportioning the gross receipts to the com-

6. See State ex rel. Botkin v. Welsh, 61 S. D. 593, 612, 251 N. W. 189, 197 (1933); Perkins, The Sales Tax and Transactions in Interstate Commerce (1934) 12 N. C. L. REV. 99, 102-104.

7. See Robbins v. Shelby County Taxing District, 120 U.S. 489, 497 (1887); Spalding \& Bros. v. Edwards, 262 U. S. 66,69 (1923).

8. See Texas Transport \& Term. Co. v. New Orleans, 264 U. S. 150, 155 (1924); (1936) 45 Y ALE L. J. 708, 711.

9. State ex rel. Botkin v. Welsh, 61 S. D. 593, 251 N. W. 189 (1933) ; cf. Crew Levick Co. v. Pennsylvania, 245 U. S. 292 (1917); see United States Glue Co. v. Oak: Creek, 247 U. S. 321 (1918). But cf. Ficklen v. Shelby County Taxing District, 145 U. S. 1 (1892). Gross receipts from the business of interstate transportation were at first held to be taxable by the states. State Tax on Railway Gross Receipts, 15 Wall. 284 (U. S. 1872). But the Supreme Court soon overruled this decision and held such a tax invalid under the commerce clause. Philadelphia \& So. Steamship Co. v. Pentnsylvania, 122 U. S. 326 (1887). For a discussion of these cases, see Adams Mfg. Co. v. Storen, 304 U. S. 307, 322-3 (1938). See also p. 284 et seq., infra.

10. Old Dominion S. S. Co. v. Virginia, 198 U. S. 299 (1905) ; Minnesota v. Blasitu, 290 U. S. 1 (1933).

11. U. S. Express Co. v. Minnesota, 223 U. S. 335 (1912) ; Pullman Co. v. Richardson, 261 U. S. 330 (1923). 
merce carried on within the taxing state. ${ }^{12}$ And a tax on net income is valid even though based upon receipts from interstate commerce. ${ }^{13}$

This disregard of practical effect also appears in those cases which turn on the question of whether the tax-burdened activity is itself interstate commerce or is only indirectly connected with it. In the so-called "drummer cases" a license tax has been held invalid as a levy on interstate commerce itself when exacted from salesmen soliciting orders for goods to be shipped into the state only after acceptance of the orders by an out-of-state seller. ${ }^{14}$ On the other hand, this same tax will be upheld when assessed against salesmen engaged exclusively in vending goods shipped into the taxing state prior to consummation of the sale. Though the ultimate burden on the transported goods, in terms of added cost to the consumer, is the same in both cases, the courts find application of the tax to the second situation to be only an indirect levy on interstate commerce. ${ }^{15}$ Even more unrealistic is the distinction drawn by the American Mannfacturing case ${ }^{16}$ between a tax levied on the privilege of manufacturing and one assessed against the privilege of selling. The former is valid, being considered at most an indirect levy on commerce even though it is measured by a percentage of both intrastate and interstate sales of the goods produced. ${ }^{17}$ The latter, on the other hand, though measured in exactly the same manner, is invalid, being said to constitute a direct levy on the very privilege of engaging in interstate commerce. ${ }^{18}$

These decisions clearly indicate that the cloak of constitutional protection thrown about interstate dealings is by no means impenetrable. Provided that the statute is so worded as to fall within the protection of established legal dogmas, the tax will be upheld despite any burden it may lay on interstate

12. Maine v. Grand Trunk Ry., 142 U. S. 217 (1891); see Western Live Stod: v. Bureau of Revenue, 303 U. S. 250, 256 (1938).

13. United States Glue Co. v. Oak Creek, 247 U. S. 321 (1918); cf. Pcek \&. Co. v. Lowe, 247 U. S. 165 (1918) (federal tax on net income held to be only an indireet and remote burden on foreign exports).

14. Rearick v. Pennsylvania, 203 U. S. 507 (1906) ; Real Sills Arills v. Portland, 268 U. S. 325 (1925). In these cases the phraseology generally employed is that a state may not tax the privilege of engaging in interstate commerce. See Cooney v. Mfountain States Tel. Co., 294 U. S. 384, 392, n. 4 (1935).

15. Wagner v. City of Covington, 251 U. S. 95 (1919).

16. American Mfg. Co. v. St. Louis, 250 U. S. 459 (1919).

17. It is regarded as a tax on a local privilege. See note 33 , infro. Compensating use taxes imposed upon the use within the taxing state of property purchased in interstate commerce have been upheld as being taxes on the local privilege of using after the interstate transportation has ceased. See p. 286, infra. There is a doctrinal limitation that the tax may not be imposed on the use of an instrumentality in interstate commerce. Helson \& Randolph v. Kentucky, 279 U. S. 245 (1929) (tax: on the use of gasoline in a ferryboat). But the Supreme Court has restricted this limitation in its more recent decisions. Nashville, Chat. \& St. L. Ry. v. Wallace, $28 S$ U. S. 249 (1933) (tax on storage and withdrawal of gasoline); Edelman v. Boeing Air Transport, Inc., 289 U. S. 249 (1933) (use tax construed as tax on withdrawal from storage).

18. See Crew Levick Co. v. Pennsylvania, 245 U. S. 292, 297 (1917). 
commerce. ${ }^{19}$ Many states, however, have preferred the administrative simplicity afforded by a sales tax to more ingenious statutes by which the interstate merchant could be reached. Clearly, application of interstate commerce doctrine to a sales tax statute deprives the state of revenue otherwise obtainable from interstate merchants. Yet the chief objection to such application has not been this loss of revenue ${ }^{20}$ but rather the burden placed upon the local merchant by permitting some of his competitors to go tax free. ${ }^{21}$ He is saldled with the discriminatory burden of the tax in his struggle against out-of-state competitors who sell through drummers or mail order catalogues. ${ }^{22} \Lambda$ number of plans have been suggested to rectify this situation. These include a federal sales tax on interstate sales, ${ }^{23}$ a Congressional statute granting permission to the states to tax interstate sales, ${ }^{24}$ and state compensating taxes upon the use and consumption of articles which have not been exposed to the state sales tax. ${ }^{25}$ Only the last of these devices has been put into actual operation, ${ }^{26}$ and even its adoption is as yet very limited. ${ }^{27}$

Although dissatisfaction with the application of hoary interstate commerce doctrines to increasingly prevalent sales taxation has not yet found expression in Congressional action, it would seem to be reflected in the growing liberal attitude of the Supreme Court. Adherence by the Court to Justice Holmes' assertion that "interstate commerce must pay its way" 28 may be inferred from

19. "In plain economic fact the states can tax interstate commerce if they go about it in the right way." Powell, Contemporary Commerce Clatse Controwersies oucr Statc Taxation (1928) 76 U. of PA. L. REv. 773, 774.

20. Sales taxes have proved to be satisfactory answers to state budgetary necds in times of emergency. See Haig \& Shoup, op. cit. supra note 5, at 37-38 and 100-101; Baum, Legal Phases of Local Sales Tax (1936) 14 N. Y. U. L. Q. REv. $28,58$.

21. This injury was the source of most of the discussion during the investigation by Congress of this field in connection with a proposed statute allowing the state to tax: interstate sales. See note 22 , infra. It has been unsuccessfully argued that, once a tax has been held invalid as to interstate merchants, it is unreasonably discriminatory against local merchants and so should be held invalid as to them also. See Robbins v. Shclby County Taxing District, 120 U. S. 489, 499 (1887).

22. For an example see Montgomery Ward \& Co. v. Fry, 277 Mich. 260, 260 N. W. 166 (1936). See in general Hcarings before Subcommittee of the Committe an Interstate and Forcign Commerce on H. R. 8303, 73d Cong., 2d Sess. (1934); Gushman, 'Th" Sales Tax and Interstate Commerce (1936) 2 Оноо St. L. J. 260, 265 ct seq.

23. Report of Interstate Commission on Conflicting Taxation (1935) 64.

24. Such a bill, known as the Harrison Resolution, was passed by the Senate in 1934 with virtually no discussion. 78 CoNg. Rec. 4597-4598 (1934). The bill died in the House Committee. For discussion of the constitutionality of such a measure, sre Lowndes, Statc Taxation of Interstate Sales (1935) 7 Miss. L. J. 223 ; Perkins, loc. cit. supro note to.

25. See (1936) 45 Yale L. J. 708; (1936) 9 So. Chlif. L. Rev. 259. See note 17, supra, and discussion at p. 286 , infra.

26. See notes 89,90 and 91 , infra.

27. There is a tremendous amount of administrative difficulty involved in locating prorerty that is being used within the state but was purchased out-of-state or in interstate commerce. See Lowndes, supra note 24, at 231 ; Perkins, supra note 6 , at 106-107.

28. See New Jersey Bell Telephone Co. v. Tax Board, 280 U. S. 338, 351 (1930). This demand was first voiced by Justice Clarke. See Postal Tel. Cable Co. v. Richmond, 249 U. S. 252, 259 (1919). 
some relatively recent state tax power extensions developed through strained manipulations of orthodox commerce clause doctrines. In the case of $C^{\prime}$ tah Power \& Light Company v. Pfost ${ }^{29}$ the Court stretched logic to the breaking point in order to uphold a state tax without doing violence to traditional concepts. Idaho imposed a license tax on the generation of electrical energy for barter, sale, or exchange and provided that the number of kilowatt hours of electricity produced should be the measure of the tax.30 Much of the petitioner's electricity was sold in neighboring states, ${ }^{31}$ but the court hell that no burden on interstate commerce resulted from application of the Idaho tax to these sales. It reasoned that the power company was really engaged in two operations-the conversion of water power into electrical energy, and the transmission of that energy to consumers. The troublesome fact that conversion and transmission are substantially instantaneous was dismisset as irrelevant since, when viewed from the "practical standpoint of taxation," the transmission occurred after the generation was complete. ${ }^{32}$ Consequently, a tax could be imposed upon the latter as a local operation without any direct effect upon the subsequent interstate commerce. ${ }^{33}$

Judicious use of existing doctrine to faror state taxation of interstate commerce has not been limited to liberal determinations of what constitutes a lucal activity. The original package doctrine ${ }^{34}$ seems to have been facilely manip-

29. 286 U. S. 165 (1932).

30. Idaho Laws Extraordinary Sess. 1931, c. 3, § 1 .

31. See Utah Power \& Light Co. v. Pfost, 54 F. (2d) 803,804 (S. D. Idalso 1931 ).

32. Utah Power \& Light Co. v. Pfost, 286 U. S. 165,179 (1932). The lower federal court went into an even more involved discussion on technical grounds to show that generation and transmission were in fact separate operations. The decision emplasizes the fact that a transformer had to be interposed before the electricity could be transmitted over the system. See Utah Power \& Light Co. v. Pfost, 54 F. (2d) 803,805 (S. D. Idaho 1931). Compare Fisher's Blend Station, Inc. v. State Tax Comm., 297 U. S. 650 (1936), where the Supreme Court invalidated a tax on the gross receipts from radio broadcasting, refusing to hold that the broadcasting company was merely in the loeal business of furnishing the station and the facilities while the customers who bought the time did the broadcasting. For further discussion of this case see p. 283, infra.

33. For similar cases involving liberal interpretations of local activities, see East Ohio Gas Co. v. Tax Comm., 283 U. S. 465 (1931); Gwin, White \& Prince, Ine. v. Henneford, 75 P. (2d) 1017 (Wash., Feb. 9, 1938). But of. Texas Transport \& Term. Co. v. New Orleans, 264 U. S. 150 (1924) ; Puget Sound Stevedoring Co. v. State Tass Comm., 302 U. S. 90 (1937). Note also that in two very recent cases discussed below the state taxes were upheld on the alternative ground that, broadly construed, the operation subject to the tax was a local one. Western Live Stock v. Bureau of Revenue, 303 U.S. 250 (1938) ; Coverdale v. Arkansas-Louisiana Pipe Line Co., 303 U. S. 604 (1938). See p. 282, infra.

34. This doctrine, as originally evolved by Chief Justice Mrarshall [Brown v. Maryland, 12 Wheat. 419 (U. S. 1827) ], was based partly on the commerce clause and partly on the constitutional provision prohibiting a state from laying "imposts or duties on imports or exports." See Sharp, Mrocement in Supreme Court Adjudication III (1933) 46 HaRv. L. Rev. 593, 605. See in general Jones, Some Constitutional Limirations on State Sales Taxes (1936)" 20 Minn. L. Rev. 461. 
ulated to achieve the same result. Though sales of imports from foreign countries are immune from state taxation so long as the goods remain in the original package, ${ }^{35}$ like protection has been denied similar sales when the goods were shipped into the taxing jurisdiction from a sister state. ${ }^{30}$ Thus in permitting taxation of interstate sales of goods, the applicability of the original package doctrine has been denied. Nevertheless, the original package concept has been preserved as a convenient analogy to demonstrate when interstate commerce comes to an end in the case of the transportation of natural gas. Thus, an Ohio tax on the sale of gas to Ohio consumers ${ }^{37}$ was held valid, even though the gas had moved in interstate commerce, on the ground that the change from the high-pressure transportation pipes to low-pressure distribution pipes was like the breaking of an original package so that the contents might be treated, prepared for sale, and sold at retail. ${ }^{38}$ The distribution from the low pressure pipes, therefore, was regarded as a local transaction which Ohio was free to tax..$^{30}$

In recent years the Court has not been satisfied with the scope of extension of state taxation which could be achieved within the bounds of existing doctrines, and has subtly begun to undermine the very foundations of the restrictions formerly thought to be inherent in the commerce clause. Wiloil Corporation v. Pennsylvania ${ }^{40}$ is the first of a series of cases to undertake such an approach. A Pennsylvania tax on the distribution of gasoline measured by the number of gallons sold ${ }^{41}$ was upheld when applied to a sale by the vendor's agents in Philadelphia for delivery in that city, despite the fact that the gasoline was actually delivered from Wilmington, Delaware. Since the vendor at the time of the contract did not own the gasoline required by the agreement and could purchase it either from within or without Pennsylvania, the Court ruled that the contract pertained to unascertained goods ${ }^{42}$ and did

35. Anglo-Chilean Nitrate Sales Corp. v. Alabama, 288 U. S. 218 (1933).

36. Sonneborn Bros. v. Cureton, 262 U. S. 506 (1923), (1924) 33 YALE L. J. 321; see Wiloil Corp. v. Pennsylvania, 294 U. S. 169, 175 (1935).

37. Ohio Gen. Code Ann. (Page, 1926) § 5483.

38. East Ohio Gas Co. v. Tax Comm., 283 U. S. 465, 470-471 (1931) ; cf. State Tax Comm. v. Interstate Natural Gas Co., 284 U.S. 41 (1931).

39. Another example of the court's growing interest in the expansion of state taxing power over interstate commerce may be seen in the recent history of the old case of Ficklen v. Shelby County Taxing District, 145 U. S. 1 (1892). There a state income tax measured by the number of commissions received, i.c., a gross receipts tax, was upheld even though the taxpayer bringing suit was engaged wholly in interstate com* merce. The decision was so limited by subsequent cases that it has since been cited as an example of a situation where the Supreme Court has overruled a former decision. Burnet v. Coronado Oil \& Gas Co., 285 U. S. 393, 408, n. 2. (1932). It has recently reappeared, cited as good authority, in decisions expanding the taxing power of the states. Western Live Stock v. Bureau of Revenue, 303 U.S. 250, 258 (1938); Gwin, White \& Prince, Inc. v. Henneford, 75 P. (2d) 1017 (Wash., Feb. 9, 1938).

40. 294 U. S. 169 (1935).

41. PA. Stat. (Purdon, 1936) tit. 72, § 2611 d.

42. The orders specified a price per gallon "f. o. b. Wilmington, Del., plus 3c. tax," but the court construed this as being price-fixing only and not as an indication of the 
not "require or necessarily involve" interstate transportation..$^{33}$ Consequently, the commerce clause was said to afford no protection to the transaction. The decision leaves unanswered many questions as to the existence of interstate commerce. A particularly perplexing problem arises, for example, when the contract itself does not call for interstate shipment ${ }^{24}$ but the seller either owns available sources of supply both within and without the state or else has the choice of obtaining the goods by purchase from an in-state competitor or of shipping from his own warehouse in another state." At most, the IViloil case only points the way towards an enlargement of state power over interstate commerce, and later cases in state courts have tended to limit its implications. ${ }^{40}$ Its rationale has been held inapplicable to situations involving "special orders" for particular goods, and courts have been lenient to the taxpayer in determining what constitutes a "special order." 4 it Even though the Wiloil case does restrict the definition of an interstate sale to some degree, its efficacy as an aid in extending the scope of state taxation is questionable. The more specific the judicial definition of an interstate sale, the more easily may astute counsel mould transactions to fit that definition. ${ }^{18}$

source or place of shipment. Wiloil Corp. v. Pennsylvania, 294 U. S. 169, 173 (1935). See Warren \& Schlesinger, Sales and Use Taxes:-Interstate Commerce Pays Its Way (1938) 38 CoL. L. Rev. 49, 57 ct seq.

43. The forerunners of this decision are two cases dealing with the buying and selling of cotton for future delivery. Such contracts were ususlly speculative and did not result in actual delivery. The Supreme Court held that even when they did result in interstate delivery the seller was free to acquire the cotton in the market where the delivery was made or elsewhere; hence the sales vere not in interstate commerce. Ware \& Leland v. Mobile County, 209 U. S. 405 (1908) (license tax on brolsers dealing in cotton futures) ; cf. Moore v. N. Y. Cotton Exch., 270 U. S. 593 (1926) (federal jurisdiction question); Banker Bros. v. Pennsylvania, 222 U.S. 210 (1911) scmble.

44. The language in one part of the opinion may be interpreted to hold that interstate commerce may exist even though the contract does not require interstate shipment so long as it is contemplated. See Wiloil Corp. v. Pennsylvaniz, 294 U. S. 169, 175 (1935). But cf. Warren \& Schlesinger, supra note 42, at 59. Cf. Dahnke-Waller Miflling Co. v. Bondurant, 257 U. S. 282 (1921) (state police power); Lemlse v. Farmers Grain Co., 258 U. S. 50 (1922) (same).

45. But it must be noticed that, as the court points out, it was not shown that when the contract was made the appellant had any fuel of the lind covered in the contract or that the fuel to be delivered was then in existence. Wiloil Corp. v. Pennsylvania, 294 U. S. 169, 173 (1935); cf. Compagnie General Transatlantique v. AfcGoldrick, 4 N. Y. S. (2d) 661 (App. Div. 1st Dep't, Mlay 27, 1938). See Johnson, Slate Sales Ta.r and the Commerce Clause (1936) 24 Caurr. L. Rev. 155.

46. But cf. McNeel Marble Co. v. Graves, 247 App. Div. 242, 288 N. Y. Supp. 58 (3d Dep't 1936), aff'd, 275 N. Y. 601, 11 N. E. (2d) 775 (1937) (per curian decision).

47. National Cash Register Co. v. Taylor, 276 N. Y. 20S, 11 N. E. (2d) S31 (1937); Williams v. Hamilton, 76 P. (2d) 1029 (Wash., Mrar. 7, 193S); Felt \& Tarant MIg. Co. v. Taylor, 4 N. Y. S. (2d) 615 (App. Div. 1st Dep't, Mray 27, 1938); Compagnie General Transatlantique v. McGoldrick, 4 N. Y. S. (2d) 651 (App. Div. 1st Dep't, May 27, 1938) ; cf. Simpson, Inc. v. O'Hara, 277 Mich. 55, 268 N. W. 809 (1936) ; Montgomery Ward \& Co. v. Fry, 277 Mich. 260, 269 N. W. 166 (1936).

48. Cf. Superior Oil Co. v. Míssissippi, 280 U. S. 390 (1930); Paramount Pictures Distributing Co. v. Henneford, 184 Wash. 376, 51 P. (2d) 385 (1935); Sheppard v. 
In the last term, the Supreme Court went still further and re-examined the fundamental concept of a direct burden on interstate commerce, explaining its past decisions in new terms. In prior cases the only criterion of a direct burden was the vague rule that when the tax caused increased financial cost to shipments in interstate commerce and the operation that was being taxed was an integral part of an interstate transaction, the tax would be regarded as a direct and therefore invalid burden on interstate commerce." In $\mathrm{Westcrn}$ Live Stock v. Burean of Revenue ${ }^{50}$ the Court propounded a more articulate test for future use. The New Mexico statute involved levied a privilege tax on the gross receipts from advertising of any person engaged in the publishing business. $^{51}$ The appellant company sold space to out-of-state advertisers in a journal which it published and circulated both within and without the taxing state. The court held that the preparation, printing, and publishing of the advertising matter was a local occupation ${ }^{52}$ and hence the tax was valid within the rule of the American Manufacturing Company case. ${ }^{53}$

Not content to base its opinion on this ground alone, the Court proceeded to examine the situation in the light of "reason and the practical needs of a tax system," interpreting such practical needs as embodying the double demand that interstate commerce be made to pay its way but at the same time be protected from the burden of cumulative exactions not similarly levied on local business. ${ }^{54}$ This language suggests a new general rule to the effect that a state may tax interstate commerce so long as the same transaction cannot be similarly taxed by any other state. Thus the abhorrence of double taxation which suddenly appeared during the last two decades in the Supreme Court's treatment of state property and estate taxation ${ }^{55}$ seems to have been bodily imported into the sales tax field as a new interpretation of the commerce clause. The approach is new, but the court finds little difficulty in explaining previous decisions in its terms.

Miusser, 127 Tex. 193, 92 S. W. (2d) 219 (1936); Williams v. Hamilton, 76 P. (2d) 1029 (Wash., March 7, 1938).

49. 1 Cooley, Taxation (4th ed. 1924) \$374; Gavit, The Conmerce Claust (1932) \$\$ 167, 169; Comment (1938) 24 VA. L. REv. 301.

50. 303 U.S. 250 (1938).

51. New Mex. Laws Spec. Sess. 1934, c. 7, \$201 (1).

52. Western Live Stock v. Bureau of Revenue, 303 U. S. 250, 258-259 (Feb. 28, 1938). In pointing out that all of the events upon which the tax is conditioned occur in New Mexico and not elsewhere, the court emphasized the fact that the tax is incasured by the advertising and not by receipts from subscriptions nor by the extent of the circtilation of the magazine interstate. Id. at 260 .

53. That is, it is a tax on a local privilege, the value of which is determined by gross receipts from sales both interstate and intrastate. See note 16, supra.

54. Western Live Stock v. Bureau of Revenue, 303 U. S. 250, 259 (1938).

55. See Harding, Double Taxation of Property and Income (1933) c. II; Brown, Multiple Taxation by the States (1935) 48 Harv. L. Rev. 407, 430. This development has been very pronounced in the last ten years despite the fact that until then the Supremu Court had clearly indicated that there was no rule of law, constitutional or otherwise, preventing more than one state from taxing the same property or transfer. See HanpiING, supra, at 21, n. 55. 
In the past, application of commerce clause concepts to state taxation has aroused protest by virtue of its exemption of interstate commerce from all direct tax burden and not merely from that part of the tax burden which discriminates against it. The $W$ cstcrn Live Stock case is of importance beeause it suggests a method whereby this evil may be somewhat minimized. If some doctrine may be invoked so as to expose interstate transactions to taxation in a single state only, it can be argued that such taxation is valid despite the fact that, by former standards, the exaction would be viewed as a direct burden on interstate commerce. Such a doctrine may be erected on the foundation provided by the due process prohibition against taxation of any transaction, privilege, or property outside of the state's territorial jurisdiction. ${ }^{* 0}$

Application of this doctrine to interstate sales would present a ready opportunity to extend the scope of state sales taxation. Localization of a sale to a particular jurisdiction for tax purposes would enable the Court to maintain that a sales levy by that jurisdiction is unobjectionable, since a tax by any other state would be outlawed by the due process prohibition. Hence the levy could not violate the new double taxation criterion of the commerce clause. The Supreme Court has expressly indicated that it will not be concerned with the "witty diversities of the law of sales" in reference to the passage of title and other similar factors determinative of where the sale took place, ${ }^{3 i}$ but a reversal of this policy is not impossible.

The feasibility of such an argument may be seen by reference to a typical fact situation with an individual vendor in one state selling through interstate commerce to an individual buyer in a neighboring state. There are, to be sure, two elements in the transaction which occur in separate states-shipment of the goods, and their receipt; and it is quite likely that under existing precerlent a tax on each by the respective state in which it takes place would be held to constitute a multiple tax burden within the prohibition of the I"estern Liv" Stock case. But it is apparent that there is only one sale and that it is and can be located, as a matter of sales law, in only one of the taxing states. Hence it would not seem illogical to conclude that any attempt to tax it on the part of the other state should be condemned as extraterritorial taxation and contrary to the due process clause. The development of a set of rules such as this would call for repeated excursions into the highest reaches of legal theology. but the courts have not hesitated to explore the conceptual possibilities of similar situations in determining the location of intangible property for the purposes of property taxation ${ }^{58}$ or in deciding where the transier of a de-

56. See HaIg \& Shoup, of. cit. supra note 5. at 643 et seq.; Loundes, Spurious Conceptions of the Constitutional Law of Taxution (1934) 47 H.ns. L. REx. 63, 630 at si?.

57. Rearick v. Pennsylvania, 203 U. S. 507, 512 (1906). See G.ubr, Tue CuMaree Clause (1932) 122. For a case where a state court did look into the question of the locality of the sale, see Simpson, Inc. v. O'Hara, 277 Mich. 55, 268 N. II. $\$ 99$ (1036).

58. Union Refrigerator Transit Co. v. Kentuchy, 109 L. S. 194 (1005): Suuthern Pacific Co. v. Kentucky, 222 UT. S. 63 (1911). 
cedent's estate actually occurred. ${ }^{50}$ At present, neither the vendor state nor the purchaser state may tax an interstate sale. A judicious application of the due process doctrine to such a transaction would allow one of the two states to impose a direct tax thereon without contravening the anti-double tax policy of the Western Live Stock case. The potentialities of this rationale as an expander of the state taxing power are somewhat endangered by the possibility that clever counsel could arrange transactions so that title and control would pass in the states devoid of sales levies. ${ }^{60}$ This danger, however, is minimized by the presence of sales tax statutes in twenty-six states and several municipalities, ${ }^{61}$ and the probability that other jurisdictions soon will resort to this method of taxation.

In addition, it must be emphasized that the Western Live Stock case cannot definitely be said to have established multiple taxation as the sole criterion of a direct burden. The outcome of this case, and of the subsequent Supreme Court case of Coverdale v. Arkansas-Lonisiana Pipe Line Company ${ }^{02}$ which follows its rationale, is based on the alternative ground that the privilege taxed involves a local operation and therefore the tax imposes only an indirect burden on the interstate commerce that succeeds that operation. ${ }^{03}$ As a result, there is a very real danger that the possibility of multiple taxation may not be construed in the future as being the sole criterion of validity uncler the commerce clause but as complementary to the tests already in existence. If $\mathrm{so}$, a state tax which cannot be duplicated in another state, either for practical reasons or because of the operation of the due process clause, may still be held invalid because it is a direct burden on interstate commerce as defined in previous Supreme Court decisions. While this danger is indeed present, it is minimized by a realization that the Court's attitude towards state taxation in this field, as reflected in these two opinions, is one of growing tolerance. ${ }^{04}$

59. Frick v. Pennsylvania, 268 U. S. 473 (1925); Blodgett v. Silberman, 277 U. S. 1 (1928). See Rodell, $A$ Printer on Interstate Taxation (1935) 44 YALE L. J. 1166. These decisions as to jurisdiction for tax purposes have been rationalized on varions grounds. See Harding, op. cit. supra note 55, $\$ \$ 4,5$, and 6; Lowndes, supra note 56, at 638 .

60. See note 48 , supra.

61. (1937) C. C. H. Sales Tax Laws, Western States; (1937) C. C. H. Sales Tax Laws, Eastern States.

62. 303 U. S. 604 (1938).

63. Id. at 612, 613; Western Live Stock v. Bureau of Revenue, 303 U. S. 250, 258 (1938). See note 33, supra.

64. Helvering v. Mountain Producers Corp., 303 U. S. 376 (March 7, 1938) is a third decision in the last term which expands state taxing power. There the Supreme Court expressly overruled its decision which denied to the states the right to tax the income derived by a lessee of the federal government from his oil and gas leases. The court indicated that federal immunity from state taxation would be enforced only when the interference with the functions of the federal government was more substantial than in the case of a private person invoking immunity because he is operating under a government contract or lease. By analogy this decision has been held to indicate that a state tax does not directly burden interstate commerce unless it too interferes very sub- 
The only subsequent lower federal court decision involving these issues ${ }^{05}$ refers to the above cases as a significant expansion of the taxing area of the states. ${ }^{66}$

If the Western Live Stock doctrine be construed to be the sole criterion of a direct burden on interstate commerce, then in the final analysis the expansion achieved depends upon the extent of future limitations on what constitutes a possibility of multiple taxation. The Wcstcrn Live Stock case itself suggests too broad limits for the determination of such a possibility. An earlier decision had held invalid a state occupation tax measured by the gross receipts from broadcasting of in-state radio stations. ${ }^{07}$ The Court explained this decision in terms of its new standard by pointing out that a tax, such as that in force in England, ${ }^{68}$ might be levied by another state upon reception, with the result of multiple taxation. ${ }^{69}$ This application of the test seems highly rigid and may be explained as an attempt to reconcile a past decision rather than to decide anew on a fresh set of facts. Broadcasting and reception are sufficiently distinct operations to make it questionable whether taxation of the latter by another state would be held to be multiple taxation should the case arise again. Indeed, the distinction in substance between this case and the Western Live Stock case itself seems slight. Like the printing and publishing of the advertising taxed in the latter, ${ }^{70}$ broadcasting would seem to be an operation local to the taxing state, although the gross receipts from the operations in both cases are increased in amount by virtue of the fact that these activities reach out to people in other states. ${ }^{71}$ The subsequently decided Coverdale case represents a more liberal stand on the subject of the possibility of multiple taxation. The tax there in issue ${ }^{72}$ was levied on the privilege of producing electrical energy for consumption by the producer him-

stantially with such commerce. Southern Pac. Co. v. Corbett, 23 F. Supp. 193 (X. D. Cal., May 3, 1938).

65. Southern Pac. Co. v. Corbett, 23 F. Supp. 193 (N. D. Cal., May 3, 1935).

66. Id. at 194 and 196. Indeed the court squarely reversed its previous decision on the law [Southern Pac. Co. v. Corbett, 20 F. Supp. 940 (N. D. Cal. 1937)] when it refused to dismiss the bill seeking to enjoin collection of the tax in question. The court seemed to feel that in the Coverdale and the Western Liece Stocle cases the Supreme Court virtually discarded all distinction between direct and indirect burdens and merely went through the motions of retaining the old forms. Id. at 196. See note 64, supro. But $\mathrm{ef}$. Pacific Tel. \& Tel. Co. v. Henneford, 81 P. (2d) 786 (Wash. July 29, 1938) for a case refusing to follow the lead of the Corbett case.

67. Fisher's Blend Station, Inc. v. State Tax Comm., 297 U. S. 650 (1936); ef. City of Atlanta v. Southern Broadcasting Co., 184 Ga. 9, 190 S. E. 594 (1937).

68. Wireless Telegraphy Act, 1904, 4 Edw. 7, c. 24 as explained by 15 \& 16 Geo. 5, c. 67 (1925 \& 1926). Such a tax was imposed by South Carolina but was held invalid as a burden on interstate commerce. Station WBT, Inc. v. Poulnot, 46 F. (2d) 671 (E. D. S. C. 1931).

69. Western Live Stock v. Bureau of Revenue, 303 U. S. 250, 260 (1938).

70. See note 52, supra.

71. But see the discussion of this case in note 32, supra.

72. La. Gen. Stat. ANN. (Dart, 1932) § 8790. 
self, and was measured by the amount of horse-power of the generator so employed. The taxpaying company maintained a pipe line for the interstate transportation of natural gas which it produced, and used the tax-burdened generator to furnish the power required to force the gas through the pipes in interstate commerce. To the contention that multiple taxation might result from a similar levy, by other states through which the pipe line passed, on generators located within their borders, the court replied that such hypothetical taxes would not burden the same activity either in form or substance. ${ }^{73}$ In other words, plural taxation was made possible not by interstate commerce operations, but by the repetition of a purely local activity within several states. ${ }^{74}$

In the subsequent decision of Adams Manufacturing Company v. Storcn," the Court found this approach inapplicable to a tax levied on gross income derived from trades, businesses, or commerce. ${ }^{76}$ The protesting taxpayer was a corporation which maintained a factory and principal place of business within the taxing state but sold most of its products to out-of-state and foreign buyers. The tax was held invalid for the reason that it could be imposed by any state in which the corporation transacted business. ${ }^{77}$ Had the tax been on the privilege of manufacture, it would have been valid ${ }^{78}$ since only one state, the situs of the factory, can regulate a purely local activity. Unfortunately there seems to be no way to localize the privilege of carrying on trade, business, or commerce to any single jurisdiction. ${ }^{70}$ Such privileges, by definition, are exercised in every state in which the taxpayer engages in remunerative activities. Validation of cumulative taxes on gross income by each state totched by the transaction of an interstate taxpayer would raise those very tariff barriers between states which the commerce clause was designed to prevent. ${ }^{80}$

73. Coverdale v. Arkansas-Louisiana Pipe Line Co., 303 U.S. 604, 612, 613 (1938).

74. It may be strongly argued that a state tax on gross receipts from the business of unloading out-of-state ships can be imposed by one state only and that a tax on gross receipts from the business of loading them in another state is imposed on an entirely different activity. See Texas Transport \& Term. Co. v. New Orleans, 264 U. S. 150, 157 (1924) (Brandeis, J., dissenting). Such a tax has recently been held invalid. Puget Sound Stevedoring Co. v. State Tax Comm., 302 U. S. 90 (1937). But the force of this decision seems already weakened by the holdings in the Coverdale and W'stern Lit'c Stock cases.

75. 304 U. S. 307 (May 16, 1938), rev'g Storen v. Adams Mfg. Co., 7 N. E. (2d) 941 (Ind. 1937), (1937) 37 CoL. L. Rev. 1418, (1937) 13 IND. L. J. 178.

76. Ind. Stat. Ann. (Burns, 1933) §64-2601 ct seq.

77. Adams Mfg. Co. v. Storen, 304 U. S. 307, 311 (1938).

78. American Mfg. Co. v. St. Louis, 250 U. S. 459 (1919). See notes 16 and 17, supra.

79. It is possible, of course, arbitrarily to select the state of domicile as the one state entitled to tax the gross receipts of a corporation, but such a rule would have the tundesirable result of denying to other states in which the corporation did business the power to tax any of those receipts.

80. Perkins, supra note 6 , at 104. 
Invalidation of such taxes need work no hardship on the state or its local merchants. A gross receipts tax will be upheld if levied not on the total gross income, but on the portion of that income which bears approximately the same ratio to the total as that part of the commerce carried on within the state bears to the total amount of commerce done. ${ }^{81}$ This restriction on gross receipts taxation prevents the erection of tariff barriers, and at the same time permits interstate commerce to be forced to pay its own way. Consequently, the Court's position in this case, though it constitutes no advancement in the extension of state taxation, should not be interpreted as inconsistent with attempts in the Western Live Stock and Covcrdale cases to devise methods of forcing interstate commerce to pay its way under other types of sales taxes.

In a vigorous dissent to the decision of the Storen case it was argued that, as applied to the appellant corporation, the tax in suit could not be duplicated in other states. The contention was advanced that, while a tax might be imposed by some outside state upon sales by the distributors of the appellant's goods, this was not the type of multiplication of taxes which the Westcrn Live Stock case meant to brand as unfair to interstate commerce. In this situation, each tax would be by way of return for the protection offered by the taxing state to the manufacturer in the one case, and to the distributor in the other. ${ }^{82}$ Under such circumstances the sole requirement for the validity of the two taxes should be that they be uniform and non-discriminatory in their operation in each state. ${ }^{83}$ Such an interpretation is an obvious extension of the doctrine of the Western Live Stock case, and, if accepted, would nullify virtually all restrictions on the taxability of interstate commerce.

The dissenting justice made an even more direct attack upon the double taxation standard on the ground that a state tax should not be stricken down by the courts simply because of the possibility of the multiplication of tar burdens. ${ }^{84} \mathrm{He}$ would require proof in each case not merely that the interstate commerce involved might be taxed by several states but that it was in fact so burdened. This suggestion would seem to import a more realistic attitude into the problem and would have the advantage of cutting short all speculation as to the degree of possibility required. The courts would then be spared the problem of deciding, for example, whether a tax on gross receipts of a radio station should be held unconstitutional, as mentioned above, ${ }^{85}$ because of the unlikely chance that a neighboring state might impose a tax

81. See note 12, supra.

82. Adams Mfg. Co. v. Storen, 304 U. S. 307, 330, 331 (Mfay 16, 1938) (Blacls, J., dissenting). This protection rationale has long been used by the courts as determinative of the power of each jurisdiction to impose a tax on a person, thing, or act. Sce HarnING, op. cit. supra note $55, \S 4$.

83. But the Supreme Court has repeatedly held that such taxes must also aroid being direct burdens on interstate commerce. See note 7, supra.

84. Adams Mfg. Co. v. Storen, 304 U. S. 307, 327-330 (Miay 16, 1938). Only Congress, he suggested, has the power to formulate laws to protect interstate commerce from "merely possible future unfair burdens." Id. at 328 (italics are Justice Blach's).

85. See p. 283, supra. 
upon reception at some time in the future. ${ }^{86}$ But if it were shown that two such taxes were in force, a sale would still escape taxation in both states unless the due process doctrine were invoked to limit the taxability of the sale to a single state. ${ }^{87}$ Moreover, a further disadvantage would result from requiring proof of actual multiple taxation. The state which imposed the first tax could collect it without objection, whereas other states would find the taxpayer levy-proof. The only alternative would be judicial acceptance of the dissenting justice's protection argument ${ }^{88}$ as a basis for differentiating taxes by two states on the same interstate sale, and a consequent abolition of all commerce clause restrictions on state taxation. The language of the Storen and the Western Live Stock cases indicates clearly that the Supreme Court at present will not give serious consideration to the stand advocated by this dissent.

The problem of double taxation has previously been discussed to some extent by the Supreme Court in connection with a Washington compensating use tax. ${ }^{80}$ This levy avoids multiple taxation by providing an exemption for all articles whose sale or use has previously been subject to a tax equal to or in excess of the instant tax, whether under Washington law or under the law of any other state..$^{90}$ Not all states with similar taxes, however, provide for an exemption for the taxes paid in another state. ${ }^{01}$ The question then arises whether a sales tax in one state and a use tax on the same article in another state constitute a multiple tax burden within the meaning of the Western Live Stock case. In Henneford v. Silas Mason Company ${ }^{22}$ the Supreme Court upheld the Washington tax as a levy on the exercise of a local privilege after the interstate movement of the property whose use was being taxed had come to an end. ${ }^{93}$ It refused to view this as a tax upon the foreign sale even though the tax was imposed upon the use of articles which had been bought in another state and not upon the use of those which were the subject of a gift or bequest. ${ }^{94}$ While the court expressly avoided passing

86. But see note 68 , supra.

87. See Lowndes, note 56 supra, at 638 .

88. See note 82 , supra.

89. Wash. Laws 1935 , c. $180, \S 32$ (c). The exemption has since been reduced in extent so as to include only those cases where the local sales tax has already becn paid. Wash. Rev. Stat. Ann. (Remington, Supp. 1937) § 8370-32.

90. See in general Warren \& Schlesinger, supra note 42, at 69, ct seq.; (1936) 9 So. Calif. L. Rev. 259. 267.

91. In fact, most of the states with use statutes allow exemptions for local sales taxes only. See Warren \& Schlesinger, supra note 42 , at 65, n. 73,74 and 77.

92. 300 U. S. 577 (1937).

93. Cf. Gregg Dyeing Co. v. Query, 286 U. S. 472 (1932). See note 17, stupra. But cf. Baldwin v. Seelig, Inc., 294 U. S. 511 (1935) (state police power case).

94. "One could argue with as much reason that there would be a tax upon the sale if a property tax were limited to chattels so acquired. A legislature has a wide range of choice in classifying and limiting the subjects of taxation." Henneford v. Silas Mason Co., 300 U. S. 577, 587 (1937). Thus, the legislature is free to make the tax base as broad or narrow as it pleases. Id. at 588 . 
on the multiple taxation question since it was not directly involved in the case, it did suggest a possible argument for the validity of a compensating use tax that allows exemptions only to the extent that the sales tax of the same state has been paid. It pointed out that a state might be treated as a self-contained unit which need not look to the taxing systems of other states in fixing the exemptions which it will allow. ${ }^{85}$

The direct question has thus not yet arisen, but if the validity of the statute providing for a use tax depends upon the presence of an exemption for foreign sales taxes that have already been paid, this would be to some extent a repudiation of the possibility of double taxation as the decisive test. There is always the possibility that the exemption clause may be repealed by the legislature. Instead, the determinative question would be that suggested by the dissent in the Storen case-is there an actual burden ?0 $^{-10}$ On the other hand, if the Supreme Court should hold that such an exemption provision is not necessary; it would clearly be a departure from the stand against multiple taxation taken in the Western Live Stock case. In the absence of such an exemption, a tax on the use of articles that have been purchased from out-of-state sources seems in fact to be a tax by the state of destination on the purchase itself, while $a \operatorname{tax}$ in the state of origin would be a tax on the sale. A decision upholding the use tax under such circumstances would be a long step towards the dissenting justice's other suggestion that the two operations be treated as sufficiently differentiated to allow taxes by both states without constituting double taxation. ${ }^{97}$ In view of the sentiment against double taxation exhibited in the Western Live Stock case, however, it is probable that the Supreme Court will in effect espouse the actual burden test by holding invalid those use taxes which allow only the narrow exemption. ${ }^{88}$

\section{Conclusion}

As a result of the development of the Supreme Court's interpretation of the commerce clause, it is clear that the states can in fact tax interstate commerce, but that their taxing statutes must be couched in careful language. The most comprehensive state taxing system would provide for a tax on the privilege of engaging in a local occupation measured by the gross receipts therefrom. Provision would have to be made for the apportionment of these receipts so that, in the case of a company doing interstate business, the tax would be determined by the amount of that business done within the taxing

95. Id. at 587. In another part of the opinion, however, the court seems to lean heavily on the fact that deductions are allowed for foreign sales taxes in deciding that interstate commerce is not burdened by this general use tax. Id. at 581 and 584.

96. See note 84 , supra.

97. See note 82, supra.

98. But before the Silas Mason case a tax on the storage for use of gasoline with only a narrow exemption was held valid without discussion of the double tasation question. Gregg Dyeing Co. v. Query, 286 U. S. 472 (1932). 